\title{
Organisational Factors as Antecedents of University Academic Staff Research Productivity
}

\author{
Geoffrey Boaz Hiire $^{1 *} \quad$ Joseph Oonyu $^{2} \quad$ Robert Kyaligonza $^{1} \quad$ David Onen $^{1}$ \\ 1.East African School of Higher Education Studies and Development (EASHESD) \\ 2.School of Education (SoE) \\ College of Education and External Studies, Makerere University, Uganda
}

\begin{abstract}
This study explored whetherorganisational factors such as technological progress, computer skills, research funding, and human resourceswere significant antecedents of academic staff research productivity in chartered private universities in Uganda. The study stemmed from reportedly low levels of research productivity of the academic staff in private universities in the country in spite of the numerousinterventionsby the Government of Uganda to spur research in both public and private higher education institutions.Using the quantitative approach anddescriptive cross-sectional survey research design, the researchers collected data using a pre-testedselfadministered questionnaire from a sample of 210 academic staff drawn from four out of nine chartered private universities in the country. The data were analysed with the use of appropriate descriptive and inferential statistical techniques. The study findings showed, among others, that while technological progress $(\beta=0.425, \mathrm{p}$ $=0.000<0.05)$ and possession of computer skills $(\beta=0.329, \mathrm{p}=0.000<0.05)$ were positive and significant antecedents of research productivity, research funding $(\beta=-0.003, \mathrm{p}=0.965<0.05)$ and human resources $(\beta=$ $0.073, \mathrm{p}=0.186<0.05)$ were respectively negative and positive but non-significant antecedents of academic staff's research productivity in the universities studied. Therefore, it was concluded that although organisational factors, overall, were significant antecedents of university academic staff's research productivity, some of its elements such as technological progress and possession of computer skills were more significant antecedents than others - implying that in order to boost the research productivity of the academic staff, university managers need to place proportionate emphasis on these factors if they are to create an enabling research environment in their institutions.
\end{abstract}

Keywords: Organisational factors, Antecedents, Academic staff, Research productivity, Universities

DOI: $10.7176 / \mathrm{JEP} / 11-18-11$

Publication date: June 30 th 2020

\section{Introduction}

In today's knowledge economies, there is mounting pressure on universities, world over, to becomestewards of public knowledge creation and innovation through their research function (Kyaligonza, 2015). But, this pressure is essentially being mounted directly on the academic staff - whom together with their students - are expected to engage in the advancement and creation of scientific and technological knowledge through their research activities(Ndege, Migosi\&Onsongo, 2011). However, the research productivity of several academic staff in universities in developing countries in terms of their research publications often leaves a lot to be desired. The case of research productivity of the academic staff in chartered private universities in Uganda has not been an exception. In this study, the researchers explored whether organisational factors such as technological progress, computer skills, research funding, and human resources were significant antecedents of academic staff's research productivity in chartered private universities in Uganda in order to devise ways through whichthe research productivity of the academic staff in these institutions can be raised. In this section, the authors present the background to the study and the research objectives.

Historically, research was not one of those core functions of the university professor (or academic staff) whose initial role was majorly to teach. But, this trend changed from early $1800 \mathrm{~s}$ when Wilhelm von Humboldt, a Prussian minister, diplomat and philosopher founded the University of Berlin in 1810 in which he envisioned "an institution that intimately intertwined research and education under one roof, giving students direct access to the leading researchers and thinkers of the time" (EMBO Rep., 2007, para 1). Since then, research has become an integral role of any university teacher, to extent that today, many universities do not focus on teaching ability in order to hire new faculty but simply look at the publications list (Sawyerr, 2004). In fact, frequent publication is now one of the few powerful methods at a scholar's disposal to demonstrate his/her academic talent to peers and universities now also use the number of publication to an individual's credit as the measure of competency. This has brought immense pressure on academic staff to publish (Kasozi, 2008) and the phrase "Publish or perish" initially coined by Coolidge in 1932 is now a harsh reality for thosewho teach at universities (Rawat\&Meena, 2014). However, not many academic staff are as productive in terms of research as required due to several factors or constraints. In this study, the researchers explored whether organisational factors significantly influence the research productivity of academic staff in chartered private universities in Uganda. 
Conceptually, there were three key terms in this study. First, was the term organisational factors.According to Davis and McKee (2005), organisational factors are the things or "factors [that] influence the way ... things are done within [an] organization, [including] the rules and regulations that are enforced, normal or expected patterns of behaviour, and even the structure of the organization" (p.120). But according to Elanain (2009),organizational factors are the job characteristics that influence behaviour at work. In the context of this study, organizational factors were looked at in terms of those things or issues believed to influence the research productivity of the academic staff such as employee skills (Huselid, 1995), funding (Musiige\&Maassen, 2015), technological progress and computer skills (Worthington \& Lee, 2008) as well as physical and human resources (Oyekan, 2014). The second key concept in this study was antecedent. The phrase antecedentis derivedfrom two Latin words: 'ante', which means "before" or "to proceed" and 'cedere', which means "to yield" (Delmonte, 2007). In this study, the phrase was used to refer to already existing factors that lead something to happen specifically the factors that influence the research productivity of the academic staff. Finally, the third and last important concept in this research was research productivity. The term research productivity is defined differently by different scholars. According to Usang, Akuegwu, Udida andUdey (2007), research productivity is a measure of the research publications of an individual or institution. This definition of research productivity is widely accepted among scholars. This explains why according to Reed, Enders, Lindor, McCleesandLindor (2011), research productivity is defined as the number ofauthored or co-authored textbooks, book chapters, journal articles, and conference papers that an individual or group publishes. Kyaligonza(2015) and WamalaandSsembatya(2015)also add that research productivity is a measure of the number and quality of technical reports, conference papers, working and occasional papers that an individual or a group produces for the scientific community. In this study, research productivity was characterized by the above stated measures of the concept.

This study was conducted in chartered private universities in Uganda. Out of the over 45 private universities in the country, only nine of them are chartered. According to the Universities and Other Tertiary Institutions [UOTIA] Act of 2001 (as amended in 2006), by having a charter, it means that such a university is already fully licensed and is now comparable to a public university (Uganda Government, 2001). As a result, society expects such a university to play its core role of conducting high-level teaching, research and community engagement. Unfortunately, both public and private universities in Uganda are reportedly not adequately playing their research function. According to the National Council for Higher Education (NCHE] (2018), the research productivity of the academic staff of most private universities in Uganda have remained low. In the NCHE's report of 2015/16 on the state of higher education in Uganda, it was reported that the productivity of $\mathrm{PhD}$ academic staff in terms of publication, for instance, was less than 10 publications in over 20 -year period per staff. This was worrying since the private universities tend to enrol a large number of students comparable to the number of academic staff that they employ. This scenario prompted the researchers to investigate the factors that could be influencing the research productivity of the academic staff in these institutions; thus, the genesis of this study.

Study objectives. This study was intended to explore whether organisational factors such as technological progress, computer skills, research funding, and human resources were significant antecedents of academic staff's research productivity in chartered private universities in Uganda. Specifically, however, the study was aimed at achieving the following research objectives:

i. To determine whether research funding is a significant antecedent of academic staff research productivity;

ii. To establish whether technological progress is a significant antecedent of academic staff research productivity;

iii. To find out whether possession of computer skills is a significant antecedent of academic staff research productivity; and

iv. To determine whether human resources are significant antecedents of academic staff research productivity.

\section{Literature Review}

2.1. Theoretical Review. This study was anchored on the theory oforganisational contingency that was developed by Lawrence and Lorschin 1967. According to the theory, there is no single right method of doing anything; it is the context that dictates the best approach to how anything can be done or accomplished. Therefore, since research projects, in this case, are novel by definition, they require a different contingent approach on each instance, simply because most variables have changed to some extent (Kureshi, 2013). Thus, no general organisation principles exist to guide how many different things in a work organisation should be carried out including research (Matyusz, 2012). Therefore, in this study, the researcherstheorised that organisational effectiveness is dependent on a fit of individual organisation's specific factors and the higher the interaction of structural dimensions of work design influence organisational adaptation to environment. This was because, 
according to the contingencytheory, the more organisation structures fit their respective environments more coherently, the more they are likely to outperform those that do not (Leweling, 2007). Therefore, the researchers conjectured that if specific organisational factors such as research funding, human and physical resources, and technological progress interact with institutional environment, there will be increase in the research productivity of the academic staff in the universities studied.

2.2 Review of related literature. Different scholars such as Hadjinicolaand Soteriou (2006), Hedjaziand Behravan(2011), Kyaligonza(2015), Musiigeand Maassen(2015), Mugimu, Nakabugo and Katunguka (2013), and Oyekan(2014) have all investigated the organizational factors that significantly relate with the research productivity of university academic staff and they have all emerged with diverse, and at times, contradictory findings. Bland, Center, Finstad, Risbey and Staples(2005)for instance tested the ability of individual, institutional and leadership variables in influencing faculty research productivity using data from the University of Minnesota Medical School - Twin Cities. Their regression results revealed that faculty productivity was influenced more by institutional rather than personal characteristics. Hadjinicola and Soteriou (2006) on the other hand investigated factors that promote the research productivity of the researchers in US Business schools. Their findings revealed that three factors increased both the research productivity and the quality of the articles published by the professors in the Business schools. These factors were: presence of a research centre, funding received from external sources for research purposes and better library facilities. In another study, Hedjazi and Behravan (2011) analyzed the relationship between individual, institutional and demographic characteristics on one hand and the research productivity of agriculture faculty members all over Tehran Province on the other hand and discovered that institutional characteristics, namely: network of communication with colleagues, resources of facilities, corporate management and clear research objectives were significant predictors of the agricultural faculty members' research productivity. These studies were however slightly different with the current study in two major ways. First, the earlier studieswere restricted to academic staff in a few faculties or schools. The current study meanwhile was done across staff members of academic staff of different schools or faculties. Second, the earlier studies were also virtually all done outside Africa. The current study on the other hand was undertaken in private universities and in the context of a developing nation. The researchers thereforebelievedthat there could be some difference in the findings on the current study with that of theearlier ones; thus, the justification for this study.

Some other studies on the factors affecting the research productivity of academic staff in universities in Africa had also been carried out by some scholars. Kyaligonza (2015) for instance investigatedthe factors that influenced the research productivity of the academic staff in public universities in Uganda. His descriptive results revealed that institutional factors had a moderate effect on the research productivity of the academic staff in the universities studied. However, this study was basically focussed on public universities unlike the current one. Further, Kyaligonza, Kimoga andNabayego (2015) also looked at the influence of funding on the research productivity of academic staff in universities, again, in Uganda. Their study findings revealed that funding can positively influence research productivity in universities and colleges. This finding was somehow corroborated with that of Musiige and Maassen (2015) who explored the faculty perceptions and experiences with respect to the factors that influence their research productivity at Makerere University, also found in Uganda. The findings of the Makerere study revealed that organisational factors and funding had a major impact on the nature and sustainability of research productivity. This kind of scenario was not very different with what Oyekan (2014) reported in his study in which he examined the factors that determine the research productivity ofacademic staff in Nigerian Universities. Indeed, with the use of correlational analysis, Oyekan reported that resource situation factors such as physical, human and material resources have significant positive relationships with academic staffs' research productivity. It is thiskind of result and others mentioned above which the current study intended to verify; thus, the needfor this investigation.

\section{Method}

3.1 Research Approach and Design. This study was conducted basing on the positivist research philosophy. This was premised on the belief that the study variables such as research productivity could easily be measured. As a result, using the quantitative approach would easily yield data that could answer the research questions. Specifically, the study was conducted using the descriptive cross-sectional survey research design where data were collected from a cross-section of academic staff at one point in time in order to avoid returning to the field several times if the design was longitudinal in nature. The design was a survey because the researchers intended to generalizethe findings from the sample to the entire target population of the study. Therefore, this design also made it cheaper to collect data from the sampled population in order to understand the issues under investigation for the entire study population.

3.2 Study Population and Sampling Procedure. The study targeted all the academic staff of the nine chartered private universities in Uganda.However, data were collected from 210 academic staff drawn from four out of nine chartered private universities in Uganda. This was a 40 percent coverage of the study population which was 
well above the minimum 10 percent conventionally recommended in survey studies.

3.3 Data Collection.Data were collected with the useof a self-administered questionnaire (SAQ) which items were adapted as follows: research productivity(from Abba\&Mugizi, 2018); research funding (from Doh, Jang, Kang \&Han, 2018); technological progress (from Bruner, Kumar \&Heppner, 2007); computer skills (from Boot et al., 2013), and human resources (from Vidotto, Ferenhof, Selig \&Bastos, 2017). The items were generally close-ended and based on a five-point Likert scale.

3.4 Data Management and Analysis.After data collection, theresearchers coded and enteredthe data into the computer using the Statistical Package for Social Scientists (SPSS) program. Thereafter, the data were analyzed with the use of assorted descriptive and inferential statistical techniques including means, standard deviations, Pearson correlation and regression analyses. The results of the study are presented in the next section.

\section{Results}

4.1 Background characteristics. This section presents the background characteristics of the study respondents which were looked at in terms of the sex, age, marital status, highest academic qualification, and the current professional rank of the individual study participants. The results on the distribution of respondents by their background characteristics are presented in Table 1.

Table 1: Distribution of Respondents by Background Characteristics

\begin{tabular}{|c|c|c|c|}
\hline Characteristic & Attributes & Frequency & Percent \\
\hline \multirow[t]{3}{*}{ Sex } & Male & 126 & 60.00 \\
\hline & Female & 84 & 40.00 \\
\hline & Total & 210 & 100.00 \\
\hline \multirow[t]{5}{*}{ Age group } & Less 30 years & 34 & 16.19 \\
\hline & $30-40$ years & 31 & 14.76 \\
\hline & $41-50$ years & 47 & 22.38 \\
\hline & Above 50 years & 98 & 46.67 \\
\hline & Total & 210 & 100.00 \\
\hline \multirow[t]{5}{*}{ Marital Status } & Single/Unmarried & 45 & 21.43 \\
\hline & Married & 32 & 15.24 \\
\hline & Widowed & 58 & 27.62 \\
\hline & Divorced/separated & 75 & 35.71 \\
\hline & Total & 210 & 100.00 \\
\hline Highest Level of & Bachelor's Degree & 39 & 18.60 \\
\hline \multirow[t]{4}{*}{ Education } & Master's Degree & 151 & 71.90 \\
\hline & Doctorate $(\mathrm{PhD})$ & 19 & 9.00 \\
\hline & Others & 1 & 0.50 \\
\hline & Total & 210 & 100.00 \\
\hline \multirow{6}{*}{$\begin{array}{l}\text { Current } \\
\text { Rank }\end{array}$} & Assistant lecturers & 3 & 0.01 \\
\hline & Lecturers & 176 & 83.81 \\
\hline & Senior lecturers & 22 & 10.48 \\
\hline & Associate professors & 9 & 4.29 \\
\hline & Professors & 0 & 0.00 \\
\hline & Total & 210 & 100.00 \\
\hline \multirow[t]{4}{*}{ Terms of employment } & Permanent staff & 26 & 12.4 \\
\hline & On contract & 179 & 85.2 \\
\hline & Other & 5 & 2.4 \\
\hline & Total & 210 & 100.0 \\
\hline
\end{tabular}

The results in Table 1 indicate that there were more male $(60 \%)$ academic staff who participated in this study than their female counterparts (40\%). This was in agreement with the records of the National Council for Higher Education (2018) which showed that the academic staff of Uganda's universities was still generally male dominated. The results also showed that the largest group of the study participants were above 40 years of age (over 69\%). This could be because those who retire from public universities in Uganda often end up being employed by the private universities. The results also revealed that the majority of the study respondents were lecturers $(83.81 \%)$, holders of master's degrees $(71.9 \%)$ employed majorly on contract basis $(85.2 \%)$. These were also in line with the records of the NCHE (2018) which showed the dominance of those groups of academic staff in Uganda's universities.

4.2. Descriptive statistics on research productivity. In the study, research productivity was studied as a unidimensional concept describing the authoring of a textbook(s), a book chapter(s), patenting and certifying an invention(s), producing an occasional paper(s), authoring a journal article(s) or conference paper(s), and writing 
a technical report(s) or scientific peer-reviewed bulletin(s) within a given time period. Besides, research productivity was also looked at in terms of publishing the different types of publications with local or international publishers. Overall, the results on research productivity were as presented in Table 2.

Table 2:Descriptive statistics on the research productivity of academic staff

\begin{tabular}{|c|c|c|c|c|}
\hline $\begin{array}{l}\text { Items on Research Productivity } \\
\text { I have...in the last } 2 \text { years }\end{array}$ & Disagree (\%) & Undecided (\%) & $\begin{array}{c}\text { Agree } \\
(\%)\end{array}$ & Means \\
\hline ...authored a textbook(s) & 57.20 & 30.00 & 12.80 & 1.43 \\
\hline ...written a book chapter(s) & 56.20 & 26.70 & 17.10 & 1.64 \\
\hline ...co-authored a textbook(s) & 22.40 & 34.80 & 42.80 & 2.13 \\
\hline ...patented and certified invention(s) & 52.90 & 13.80 & 33.30 & 1.76 \\
\hline ...produced an occasional paper(s) & 43.40 & 10.50 & 46.10 & 1.94 \\
\hline ...authored a journal article(s) & 40.00 & 14.80 & 45.20 & 2.04 \\
\hline ...written a technical report(s) & 39.10 & 16.20 & 44.70 & 1.98 \\
\hline ...authored a scientific bulletin(s) & 51.90 & 13.30 & 34.80 & 1.79 \\
\hline ...presented a paper at a local conference & 40.50 & 11.40 & 48.10 & 2.01 \\
\hline ...presented a paper at an international conference & 51.40 & 13.80 & 34.80 & 1.81 \\
\hline ...authored a working paper(s) & 39.10 & 16.70 & 44.20 & 1.97 \\
\hline
\end{tabular}

$N=210 ;$ Overall Mean $=1.87$ and Standard $=0.53$

The results in Table 2 revealed that the research productivity among the academic staff of the universities studied is generally low - with an overall mean productivity of only 1.87 and a standard deviation of 0.53 (out of a maximum of 3 that correspond to Agree). Besides, the results even indicate that the productivity of the different types of research publications are low (below 2 that corresponds to Undecided) - except for the coauthorship of textbooks (mean=2.13), publication of journal articles (mean=2.04), and the presentation of scientific papers at local conferences $($ mean=2.01). The low research productivity (as indicated in Table 1)may account for having a large number of academic staff at the lower ranks in theseuniversities.

4.3Descriptive statistics on organizationalfactors. In the study, organizational factors were the independent variables and they were looked at in terms of research funding, technological progress, possession of computer skills andhuman resources. With the use of adapted tools, these variables were measured using a three-point Likert scale ranging from disagree (coded as 1) to agree (coded as 3 ). The descriptive results on organizational factors are presented in tables 3(a) to (d).

Table 3(a): Descriptive Statistics on Research Funding

\begin{tabular}{|c|c|c|c|c|}
\hline $\begin{array}{l}\text { A. } \\
\text { tems on Research Funding } \\
\text { I have...in the last two years }\end{array}$ & $\begin{array}{c}\text { Disagree } \\
(\%)\end{array}$ & $\begin{array}{c}\text { Undecided } \\
(\%)\end{array}$ & $\begin{array}{c}\text { Agree } \\
(\%)\end{array}$ & Means \\
\hline $\begin{array}{l}\text { I have received research funding from Uganda } \\
\text { government... }\end{array}$ & 67.10 & 6.70 & 26.20 & 2.35 \\
\hline I have received research funding from local government... & 22.40 & 30.50 & 47.10 & 2.22 \\
\hline I have received research funding from a private firm... & 41.50 & 17.10 & 41.40 & 1.97 \\
\hline I have received research funding from a foreign country... & 35.20 & 14.80 & 50.00 & 2.08 \\
\hline I have received research funding from this University... & 42.80 & 14.30 & 42.90 & 1.96 \\
\hline I have received research funding from another university... & 26.10 & 14.8 & 49.10 & 2.24 \\
\hline $\begin{array}{l}\text { I have received research funding from my personal } \\
\text { savings... }\end{array}$ & 35.20 & 16.70 & 48.10 & 2.03 \\
\hline
\end{tabular}

Overall Mean and Standard Deviations for research funding: Mean $=2.01 ; S D=0.59$

The results in Table 3(a) revealed that research funding among the academic staff of the universities studied is average - with an overall mean research funding of 2.01 and a standard deviation of 0.59 (out of a maximum of 3 that correspond to Agree). Besides, the results even indicate that funding from different sources is just average (around 2 that corresponds to Undecided) - except for the funding from the university (1.96) and private firms (1.97) that are rather low. This low research funding could account for the low research productivity among academic staff in private universities in Uganda. 
Table 3(b): Descriptive statistics on Technological Progress

\begin{tabular}{|c|c|c|c|c|}
\hline B. tems on Technological Progress & $\begin{array}{l}\text { Disagree } \\
(\%)\end{array}$ & $\begin{array}{l}\text { Undecided } \\
(\%)\end{array}$ & $\begin{array}{c}\text { Agree } \\
(\%)\end{array}$ & Means \\
\hline This University has acquired sufficient ICT devices & 35.20 & 18.60 & 46.20 & 2.26 \\
\hline $\begin{array}{l}\text { When new ICT innovations occur, this university } \\
\text { immediately acquires it }\end{array}$ & 41.90 & 18.10 & 40.00 & 2.01 \\
\hline $\begin{array}{l}\text { This University benefits from the acquisition of the } \\
\text { latest ICT gadgets }\end{array}$ & 43.80 & 19.50 & 36.70 & 2.11 \\
\hline $\begin{array}{l}\text { This University is usually ahead of others when it } \\
\text { comes to buying new tech devices }\end{array}$ & 42.20 & 17.10 & 40.70 & 2.00 \\
\hline $\begin{array}{l}\text { This University try to own the latest technological } \\
\text { products }\end{array}$ & 49.00 & 14.80 & 36.20 & 1.80 \\
\hline $\begin{array}{l}\text { Acquiring new technological devices is very important } \\
\text { to this university }\end{array}$ & 40.50 & 18.60 & 40.00 & 1.93 \\
\hline $\begin{array}{l}\text { I consider this University to be more innovative than } \\
\text { other universities }\end{array}$ & 41.40 & 19.50 & 39.10 & 2.23 \\
\hline $\begin{array}{l}\text { This University is willing to buy new high ICT devices } \\
\text { even to replace existing ones }\end{array}$ & 34.80 & 21.40 & 43.80 & 2.24 \\
\hline \multicolumn{5}{|c|}{$\begin{array}{l}\text { Overall mean and Standard deviations for technological progress: Mean }=2.07 ; S D=0.58 \text {. } \\
\text { The results in Table } 3(\mathrm{c}) \text { showed that the technological progress in the private universities studied were } \\
\text { moderately high - with an overall mean of } 2.07 \text { and a standard deviation of } 0.58 \text {. Besides, the results showed tha } \\
\text { most of the elements of technological progress scored above } 2-\text { which correspond to undecided. This implied } \\
\text { that technological progress could be favourably influencing the research productivity of the academic staff in } \\
\text { private universities in Uganda. } \\
\text { Table 3(c): Descriptive statistics on possession of Computer Skills }\end{array}$} \\
\hline C. Compute & $\begin{array}{c}\text { Disagree } \\
(\%)\end{array}$ & $\begin{array}{c}\text { Undecided } \\
(\%)\end{array}$ & $\begin{array}{c}\text { Agree } \\
(\%)\end{array}$ & Means \\
\hline I can send and ope & 9.50 & 0.50 & 90.00 & 2.75 \\
\hline I easily use search $\mathrm{e}$ & 28.60 & 11.2 & 60.00 & 2.27 \\
\hline I easily find information resources on the Inter & 26.70 & 11.9 & 61.40 & 2.27 \\
\hline $\begin{array}{l}\text { Finding information of interest on the Internet is easy } \\
\text { for me }\end{array}$ & 31.90 & 14.80 & 53.30 & 2.16 \\
\hline Chat using instant messaging on the computer & 33.80 & 15. & 50. & 2.07 \\
\hline $\begin{array}{l}\text { I can easily chat on the computer using internet chat } \\
\text { rooms }\end{array}$ & 41.90 & 15.70 & 42.40 & 1.95 \\
\hline $\begin{array}{l}\text { I can easily post messages to the Internet (e.g., to } \\
\text { blogs, Facebook) }\end{array}$ & 27.60 & 8.10 & 64.30 & 2.30 \\
\hline I Use a computer keyboard to type documents & 25.20 & 10.50 & 64.30 & 2.33 \\
\hline I ably use a computer mouse & 28.10 & 10.0 & 61.90 & 2.33 \\
\hline
\end{tabular}

Overall Mean and Standard Deviations for Computer skills: Mean $=2.27 ; S D=0.52$

The results in Table 3(c) revealed that the academic staff possessed moderately adequate computer skills with an overall mean possession of computer skills of 2.27 and a standard deviation of 0.52 . Besides, the results showed that the respondents moderately possessed all the relevant skills for computer use in research (with scores around 2 that corresponds to Undecided) - except for the item "I can easily chat on the computer using internet chat rooms" (mean=1.95) - implying that the possession of computer skills could also be favourably influencing the research productivity of the academic staff in private universities in Uganda. 
Table 3(d): Descriptive Statistics on Human Resources

\begin{tabular}{|c|c|c|c|c|}
\hline D. uman resources & $\begin{array}{c}\text { Disagree } \\
(\%)\end{array}$ & $\begin{array}{c}\text { Undecided } \\
(\%)\end{array}$ & $\begin{array}{c}\text { Agree } \\
(\%)\end{array}$ & Means \\
\hline $\begin{array}{l}\text { This University employees staff thatconstantly do their } \\
\text { research activities }\end{array}$ & 24.70 & 6.70 & 68.60 & 2.40 \\
\hline Academic staff in this University hasresearch skills & 23.80 & 6.20 & 70.00 & 2.42 \\
\hline $\begin{array}{l}\text { This university evaluates academicstaff research } \\
\text { activities }\end{array}$ & 29.10 & 5.20 & 65.70 & 2.30 \\
\hline In this university staff learn fromeach other & 24.30 & 4.30 & 71.40 & 2.40 \\
\hline In this university staff competence isat a suitable level & 30.10 & 3.30 & 66.60 & 2.29 \\
\hline $\begin{array}{l}\text { A program is in placeto train the staff that replaces the } \\
\text { one who leaves }\end{array}$ & 29.20 & 5.70 & 65.10 & 2.27 \\
\hline $\begin{array}{l}\text { This university supports staff to upgrade their skills } \\
\text { and qualifications }\end{array}$ & 34.80 & 3.80 & 61.40 & 2.19 \\
\hline The lecturers in this University are intelligent (gifted) & 45.20 & 0.50 & 54.30 & 2.09 \\
\hline Lecturers of this University are nationally considered & 40.00 & 1.90 & 58.10 & 2.19 \\
\hline
\end{tabular}

Overall mean and Standard deviations for human resources: Mean $=2.28 ; S D=0.60$.

Finally, the results in Table 3(d) showed that the human resources in the private universities studied were moderately sufficient - with an overall mean of 2.28 and a standard deviation of 0.60 . Besides, the results showed that none of the elements of human resources scored less than 2 - which correspond to undecided. This implied that human resources could also be favourably influencing the research productivity of the academic staff in private universities in Uganda.

4.4. Test of Research Hypotheses. In this study, four null research hypotheses were formulated to be tested. These hypotheses where stated as follows: $\mathrm{H}_{01}$ : Research funding is not a significant antecedent of academic staff research productivity; $\mathrm{H}_{02}$ : Technological progress is not a significant antecedent of academic staff research productivity; $\mathrm{H}_{03}$ : Computer skills are not significant antecedents of academic staff research productivity; and $\mathrm{H}_{04}$ : Human resources are not significant antecedents of research productivity.To perform the tests of the hypotheses, the researchers used the multiple linear regression analysis technique. This technique of data analysis does not only show the amount by which an independent variable such as research funding, technical progress or human resources individually affects the dependent variable; in this case, research productivity, but collectively too. It was therefore considered an appropriate technique for testing the hypotheses because it would determine both the individual and compound effects of the organizational factorsstudied on the research productivity of academic staff. The results of the hypothesis tests are presented in Table 4 .

Table 4: Regression analysis results on organisational factors vis-a-visresearch productivity

\begin{tabular}{lcc}
\hline Organisational Factors & Standardised Coefficients [Beta $(\beta)]$ & Significance $(\mathrm{P})$ \\
\hline Research Funding & -0.003 & 0.965 \\
Technological Progress & 0.425 & 0.000 \\
Computer Skills & 0.329 & 0.000 \\
Human Resources & 0.073 & 0.186 \\
Adjusted $\mathrm{R}^{2}=0.375$ & & \\
$\mathrm{~F}=32.186, \mathrm{p}=0.000$ & & \\
\hline
\end{tabular}

a. Dependent variable: Research productivity

b. Independent variables: research funding, Technological progress, Computer skills, and Human resources

The results in Table 4 show that, overall, organisational factors are significant antecedents of research productivity because 37.5 percent variation in research productivity is accounted for by organisational factors (see adjusted $\mathrm{R}^{2}=0.375$ ). Additionally, the results also indicate that technological progress $(\beta=0.425, \mathrm{p}=0.000$ $<0.05)$ and possession of computer skills $(\beta=0.329, \mathrm{p}=0.000<0.05)$ are positive and significant antecedents of research productivity, while research funding $(\beta=-0.003, p=0.965<0.05)$ and human resources $(\beta=0.073$, $\mathrm{p}=0.186<0.05)$ are respectively negative and positive but non-significant antecedents of academic staff's research productivity in the universities studied.This implies that the null hypotheses on whether technological progress $\left(\mathrm{H}_{02}\right)$ and possession of computer skills $\left(\mathrm{H}_{03}\right)$ are not significant antecedents of research productivity were rejected while their alternative hypotheses accepted. On the other hand, the null hypotheses on research funding $\left(\mathrm{H}_{01}\right)$ and human resources $\left(\mathrm{H}_{04}\right)$ were accepted while their alternative hypotheses rejected.

\section{Discussion}

In this study, there were four key findings. First, the study revealed that the research productivity of the 
academic staff in the private universities studied was still low(Overall Mean $=1.87$ and Standard $=0.53)$ and the organisational factors were moderate. This finding that the academic staff's research productivity was lowwas in consonant with the work of earlier scholars such as Kyaligonza, Kimoga and Nabayego (2015), Musiige and Maassen (2015), Okendo (2018) and Oyekan (2014) who investigated the issues of research productivity among academic staff in different African universities. Oyekan for instance observed that the research productivity of the academic staff in Nigerian universities was lowdue to different resource constraints. These constraints were part and parcel of the organisational factors that influence research productivity. This scenario was not any different with case of the private universities in Uganda that are equally constrained in terms of finances, and human and physical resources.

Second, the study revealed that technological progress $(\beta=0.425, \mathrm{p}=0.000<0.05)$ andpossession of computer skills $(\beta=0.329, \mathrm{p}=0.000<0.05)$ were positive and significant antecedents of research productivity. This means that these factorssignificantlyinfluencethe research productively of the academic staff. These findings were alsoin consonant with the findings of some earlier studies. For instance, Okiki (2013) and Adetomiwa and Okwilagwe (2018) had observed thatthe use of modern technologies and the possession of computer skills were significant antecedents of academic staff's research productivity. They, in fact, pointed out that having awareness and increased utilisation of electronic databases tend to enhance the research productivity of researchers. Similarly, Bhukuvhani, Chiparausha and Zuvalinyenga (2012) also reported that skills obtained in the training on use of electronic information resources by lecturers positively affected their work - including research.

Third, the study also revealed that research funding $(\beta=-0.003, p=0.965<0.05)$ has a negativebut nonsignificant influence of the research productivity of academic staff in the universities studied. This was rather strange - even to the researchers - because ordinarily, there should have occurred a positive correlation between research funding and the research productivity of academic staff. This negative correlation could have arisen from the fact that even where there has occurred increase in research funding, other factors such as lack of research knowledge and teaching loadcould have limited the increase in research productivity of the academic staff. As a result, this finding was contradictory to the findings of earlier studies which indicated that research funding generally has a positive and significant influence on research productivity of academic staff (see Kyaligonza, Kimoga\&Nabayego, 2015; Musiige\&Maassen, 2015; Okendo, 2018). In fact, Alzahrani (2011) and Sulo, Kendagor, Kosgei, Tuitoek and Chelangat (2012) reported that there exists a positive correlation between research funds that academic staff received and the number of researches produced. Therefore, the low correlation between research funding and research productivity could have arisen from other challenges affecting the research process in private universities in Uganda.

Finally, the study revealed that human resources $(\beta=0.073, p=0.186<0.05)$ have positive but nonsignificant influenceon the research productivity of the academic staff. This finding was in agreement with the finding of several earlier studies including that of Bland et al. (2005) which looked at the effect of individual factors on the academic staff's research productivity. In this study, the influence of human resources on research productivity was weak probably because the Likert scale used in measuring research productivity was not able to yield the exact measure rate of research productivity.

\section{Conclusion and Recommendations}

Drawing from the discussion above, it can be concluded that organisational factors, overall, are significant antecedents of academic staff's research productivity. In that regard, favourable organizational factors are essential for raising the level of research productivity of academic staff. The factors, however, are not equally important. Factors like technological progress and computer skills account for the difference in the research productivity among academic staff in private universities in Uganda much more that funding and human resources. Therefore, it is recommended that the management of universities should place different emphasis on the different factors that influence the research function in order to create a conducive research environment for their staff.

\section{References}

Abba, H. D., \&Mugizi, W. (2018). Performance of academic staff in polytechnics: An analysis of performance levels in North West Geo-Political Zone of Nigeria. Art Human Open Access Journal, 2(3), 198-203.

Adetomiwa, B., \&Okwilagwe, A. (2018). Awareness and use of electronic databases as determinants of research productivity of academic staff in Nigerian private universities. Global Knowledge, Memory and Communication, 67(6/7), 396-411.

Alzahrani, J., A. (2011). Overcoming barriers to improve research productivity in Saudi Arabia. International Journal of Business and Social Science, 2 (19) 50-57

Bhukuvhani, C., Chiparausha, B., \&Zuvalinyenga, D. (2012). Effects of electronic information resources skills training for lecturers on pedagogical practices and research productivity. International Journal of Education 
and Development Using ICT, 8(1), 16-28.

Bland, C. J., Center, B. A., Finstad, D. A., Risbey, K. R., \& Staples, J. G. (2005). A theoretical, practical, predictive model of faculty and department research productivity. Academic Medicine, 80(3), 225-237.

Boot, W. R., Charness, N., Czaja, S. J., Sharit, J., Rogers, W. A., Fisk, A. D., ... \& Nair, S. (2013). Computer proficiency questionnaire: assessing low and high computer proficient seniors. The Gerontologist, 55(3), 404-411.

Bruner, G. C., Kumar, A., \& Heppner, C. (2007). Predicting innovativeness: development of the technology adoption scale. In A. P. Martinhoff (Ed). Progress in wireless communications research. Nova Science Publishers, Inc (pp. 1-20).

Davis, K., \& McKee, B. (2005). Women in the military: Facing the warrior framework. In F. Pinch, (Ed.), Contemporary military issues. Kingston, Canada: Canadian Defence Academy. Doh, S., Jang, D., Kang, G. M., \& Han, D. S. (2018). Research funding and performance of academic researchers in South Korea. Review of Policy Research, 35(1), 31-60.

Delmonte, R. (2007). Computational Linguistic text processing: Logical form, sematic interpretation, discourse relations and question answering. NewYork, USA:Nova Publishers.

Doh, S., Jang, D., Kang, G. M., \& Han, D. S. (2018). Research funding and performance of academic researchers in South Korea. Review of Policy Research, 35(1), 31-60.

Elanain, H. M. A. (2009). Job characteristics, work attitudes and behaviours in a non-western context: Distributive justice as a mediator. Journal of Management Development, 28(5), 457-477.

EMBO Rep. (2007). The future of research universities. Is the model of research-intensive universities still valid at the beginning of the twenty-first century?Science and Society, 8(9): 804810.doi: $10.1038 /$ sj.embor.7401052.

Hadjinicola, G. C., \&Soteriou, A. C. (2006). Factors affecting research productivity of production and operations management groups: An empirical study. Journal of Applied Mathematics and Decision Sciences, 1-16.

Hedjazi, Y., \&Behravan, J. (2011).Study of factors influencing research productivity of agriculture faculty members in Iran. Higher Education, 62(5), 635-647.

Huselid, M. A. (1995). The impact of human resource management practices on turnover, productivity, and corporate financial performance. Academy of Management Journal, 38(3), 635-672.

Kasozi, A. B. K. (2008). The linkage of higher education to economic development. The Uganda Higher Education Review Journal of the National Council of Higher Education, 5(1), 9-14.

Kureshi, N. (2013). Project performance and contingency theory. Journal of Strategy and Performance Management, 1(2), 46-51.

Kyaligonza, R. (2015). An investigative study of research productivity of the academic staff in public universities in Uganda. Research Journal of Social Science and Educational Studies (DRJSSES), 2(4), 6068.

Kyaligonza, R., Kimoga, J., \&Nabayego, C. (2015). Funding of Academic Staff's Research in Public Universities in Uganda: Challenges and Opportunities. Makerere Journal of Higher Education, 7(2), 147162.

Lawrence, P. R., \&Lorsch, J. W. (1967). Organisation and environment.Boston, MA: Harvard Business School, Division of Research.

Leweling, T. A. (2007). Extending organisational contingency theory to team performance: an information processing and knowledge flows perspective. Unpublished thesis for the award of a $\mathrm{PhD}$ of Naval University, Monterey, California.

Matyus, Z. (2012). The effect of contingency factors on the use of manufacturing practices and operations performance. Unpublished thesis for the award of a $\mathrm{PhD}$ of Corvinus University of Budapest.

Mugimu, C. B., Nakabugo, M. G., \& Katunguka, E. R. (2013). Developing Capacity for Research and Teaching in Higher Education: A Case of Makerere University. World Journal of Education, 3 (6), 33-45.

Musiige, G., \&Maassen, P. (2015). Faculty perceptions of the factors that influence research productivity at Makerere University. African Minds Higher Education Dynamics Series, 1, 109-127.

Ndege, T. M., Migosi, J. A., \&Onsongo, J. (2011).Determinants of research productivity among academics in Kenya. International Journal Education Economics and Development, 2 (3), 288-300.

National Council for Higher Education [NCHE]. (2018). The state of higher education and training in Uganda 2015/16: A report on higher education delivery and institutions. Kampala, Uganda: NCHE.

Okendo, O. E. (2018). Constraints of research productivity in universities in Tanzania: A case of Mwenge catholic university, Tanzania. International Journal of Education and Research, 6(3), 201-210.

Okiki, O. C. (2013). Research productivity of teaching faculty members in Nigerian Federal Universities: An investigative study. Chinese Librarianship: An International Electronic Journal, 36, 99-118.

Oyekan, O. A. (2014). Resource situation as determinants of academic staff productivity in Nigerian Universities. European Journal of Globalization and Development Research, 9(1), 545-551. 
Rawat, S., \&Meena, S. (2014). Publish or perish: Where are we heading? Journal of Research in Medical Sciences: The Official Journal of Isfahan University of Medical Sciences, 19(2), 87-89.

Reed, D. A., Enders, F., Lindor, R., McClees, M., \&Lindor, K. D. (2011). Gender differences in academic productivity and leadership appointments of physicians throughout academic careers. Academic Medicine, 86 (1), 43-47.

Sawyer, A. (2004). African Universities and the challenge of research and capacity development. Dakar: CODESIRIA.

Sulo T., Kendagor, R., Kosgei, D., Tuitoek, D., \& Chelangat, S. (2012). Factors affecting research productivity in public universities of Kenya: The Case of Moi University, Eldoret. Journal of Emerging Trends in Economics and Management Sciences, 3(5), 475-484.

Uganda Government. (2001). Universities and Other Tertiary Institutions [UOTIA] Act of 2001 (as amended in 2006). Kampala: Author.

Usang, B., Akuegwu B., Udida, L. \&Udey, F.U. (2007). Academic staff research productivity: a study of Universities in South-South Zone of Nigeria. Educational Research and Review, 2(5), 103-108.

Vidotto, J. D. F., Ferenhof, H. A., Selig, P. M., \&Bastos, R. C. (2017). A human capital measurement scale. Journal of Intellectual Capital, 18(2), 316-329.

Wamala, R., \&Ssembatya, V. A. (2015) Productivity in academia: An assessment of causal linkages between output and outcome indicators. Quality Assurance in Education, 23(2), 184-195.

Worthington, A. C., \& Lee, B. L. (2008). Efficiency, technology and productivity change in Australian universities, 1998-2003. Economics of education review, 27(3), 285-298. 